\title{
DAMPAK BISNIS KULINER MELALUI GO FOOD BAGI PERTUMBUHAN EKONOMI DI KOTA SEMARANG
}

\author{
Rr. Lulus Prapti NSS, SE, Msi \\ Fakultas Ekonomi, Universitas Semarang \\ Rahoyo, SE., MM \\ Fakultas Ekonomi, Universitas Semarang
}

\begin{abstract}
ABSTRAK
Layanan Go-Food merupakan sebuah fitur layanan food delivery pesan antar makanan yang dikembangkan oleh aplikasi Go-Jek pada bulan Maret 2015. Penelitian ini bertujuan untuk mengetahui dampak Bisnis Kuliner melalui Go-food bagi Pertumbuhan Ekonomi.Penelitian ini dilakukan pada pegusaha kuliner yang sudah bergabung dengan Layanan Go-Food yang tersebar di Kota Semarang, BPS

Penelitian ini menggunkan metode penelitian kualitatif dengan menggunakan informan kunci sebanyak 4 pelaku bisnis kuliner online. Dari hasil survey yang didapatkan para pelaku bisnis kuliner online menyatakan bahwa omzet penjualan setelah bergabung dengan Layanan Go-Food meningkat dibandingkan dengan sebelum bergabung dengan Layanan Go-Food, hal ini dikarenakan Go-Food mempromosikan makanan yang di prosuksinya. Selain itu dari pihak BPS juga menyatakan bahwa sector perdagangan dalam hal ini adalah makanan dan minuman menyumbang kenaikan PDRB yang pada akhirnya meningkatkan pertumbuhan ekonomi.
\end{abstract}

Kata kunci: E commerce, Omzet Penjualan, dan Pertumbuhan Ekonomi.

\section{PENDAHULUAN}

\section{Latar belakang Penelitian}

Salah satu persoalan pokok perekonomian regional, nasional bahkan internasional adalah pertumbuhan ekonomi. Pertumbuhan ekonomi merupakan masalah ekonomi jangka panjang yang pasti tidak akan pernah selesai. Pertumbuhan ekonomi yang pesat merupakan fenomena penting yang dialami dunia hanya semenjak dua abad belakangan ini. Dalam periode tersebut dunia telah mengalami perubahan yang sangat nyata apabila dibandingkan dengan periode sebelumnya. Kemampuan manusia untuk pergi kebulan dan mewujudkan komputer canggih merupakan contoh yang nyata dari betapa jauhnya manusia telah mengalami kemajuan sejak dua atau tiga abad yang lalu.

Dari sudut pandang Ilmu Ekonomi, pertumbuhan ekonomi merupakan persoalan sekaligus tantangan yang harus dijawab oleh setiap pemerintah. Sebab, pertumbuhan ekonomi ini terkait langsung dengan dua persoalan pokok lain perekonomian, yakni (i) kemakmuran atau taraf hidup masyarakat dan (ii) penciptaan lapangan kerja yang baru bagi penduduk yang terus bertambah jumlahnya. Tanpa pertumbuhan ekonomi, kehidupan masyarakat tidak mungkin semakin makmur dan tanpa pertumbuhan ekonomi, mustahil pengangguran akan semakin berkurang. Data menunjukkan bahwa setiap $1 \%$ pertumbuhan ekonomi akan mengurangi pengangguran sebanyak 800.000 orang.

Di sisi lain, selama dua dasawarsa terakhir perekonomian dunia telah mengalami revolusi dengan hadirnya apa yang disebut Don Tappscots (1995) sebagai digital economy atau ekonomi digital. Ekonomi digital yang sepenuhnya disokong oleh lahirnya internet sekaligus mengubah pola berbelanja masyarakat, yakni dengan adanya ecommerce (Thomas Mesenbourg, 2001). E- 
Dinamika Sosial Budaya, Vol 20, No. 2, Desember 2018, pp 120-133

p-ISSN: 1410-9859\& e-ISSN: 2580-8524

http://journals.usm.ac.id/index.php/jdsb

commerce sebagai salah satu revolusi dalam bidang perdagangan telah menjadi media jual-beli dari mulai buku sampai alat berat; dari mulai makanan sampai asesoris pakaian. Tak terkecuali, alat transportasi seperti go-jek, go-car, dst.

Sebagai sektor perekonomian baru, bisnis online di Indonesia pun berkembang pesat. Bisnis yang mengandalkan jaringan internet ini memberikan dampak positif bagi bisnis yang baru. Karena bisnis ini tidak memerlukan biaya yang besar, serta tempat fisik untuk membuat usaha. (Kompasiana, 2016).

Sehingga dengan modal terbataspun, seorang pebisnis dapat tetap memulai usahanya. Tak perlu repot untuk pergi ke kantor, karena kita bisa melakukan bisnis ini dimanapun dengan menggunakan komputer yang terhubung ke internet. Kemudahan-kemudahan tersebut, secara tak langsung, memberikan pengaruh terhadap perekonomian Indonesia lewat terbukanya beragam peluang usaha yang dapat dilakukan oleh pebisnis lokal sekalipun. Dan, salah satu bidang usaha yang tumbuh pesat di era internet ini adalah bisnis kuliner.

Sebuah laporan CNN Indonesia (2017) menunjukkan bisnis kuliner secara online di Indonesia semakin berkembang dalam beberapa tahun terakhir. Hal ini salah satunya disebabkan oleh kebutuhan dan gaya hidup penduduk yang semakin tinggi. Data dari Parama Indonesia, lembaga yang membantu perusahaan start-up berkembang, menyatakan sektor kuliner Indonesia tumbuh rata-rata tujuh hingga 14 tahun dalam lima tahun terakhir.Keberadaan bisnis online pelanpelan membunuh bisnis konvensional. Sehingga seorang pengusaha harus bisa berpikir bagaimana cara mereka bertahan hidup.

Semakin berkembangnya usaha kuliner terutama di kota-kota besar beberapa tahun terakhir ini dikarenakan kebutuhan masyarakat perkotaan yang makin meningkat. Dengan kesibukan kerja mereka yang semakin tinggi membuat mereka makin sering memesan makanan dari luar rumah. Apalagi sekarang didukung oleh perkembangan internet yang makin memudahkan mereka untuk memesan makanan dari mana saja. Kebiasaan masyarakat ini membuka lapangan usaha bagi mereka yang ingin menekuni dunia bisnis kuliner.

Bisnis kuliner mampu meraup keuntungan puluhan juta hingga ratusan juta rupiah. Data ini serupa dengan yang dimiliki oleh Badan Ekonomi Kreatif Indonesia (Bekraf). Deputi Akses Permodalan Bekraf Fadjar Hutomo dalam kesempatan sama menyebut bisnis kuliner memberikan kontribusi terbesar untuk sektor ekonomi kreatif. Fadjar menjelaskan dari 16 sektor, ada tiga sektor yang menyumbang 30 persen untuk perekonomian kreatif. Tiga sektor itu yakni kuliner, mode, dan kerajinan. Kuliner memberi sumbangsih hingga 34 persen. (Puput,CNNIndonesia2017) Karena tingkat pendapatan per kapita naik dan tumbuh, jadi peluang gaya hidup akan ikut naik. Kuliner juga akan selalu dicari, bukan makan karena lapar tapi makan karena menjadi gaya hidup.

Selama lima tahun terakhir (2013 - 2017), pertumbuhan ekonomi Kota Semarang telah menjadi penopang utama pertumbuhan ekonomi Jawa Tengah (Tribunjateng, 2017). Sekalipun mengalami naik-turun, selama lima tahun terakhir tersebut pertumbuhan ekonomi Kota Semarang selalu di atas pertumbuhan ekonomi Jawa Tengah.

Tabel 1.1 Laju Pertumbuhan Ekonomi

\begin{tabular}{|l|c|c|}
\hline & Jawa Tengah & Kota Semarang \\
\hline LPE 2013 & 5,8 & 6,6 \\
\hline LPE 2014 & 5,47 & 5,3 \\
\hline LPE 2015 & 5,4 & 5,29 \\
\hline LPE 2016 & 5,28 & 5,8 \\
\hline LPE 2017 & 5,18 & 5,7 \\
\hline
\end{tabular}


Dinamika Sosial Budaya, Vol 20, No. 2, Desember 2018, pp 120-133

p-ISSN: 1410-9859\& e-ISSN: 2580-8524

http://journals.usm.ac.id/index.php/jdsb

Sebagai salah satu kota besar di Indonesia,

Kota Semarang bisa dipastikan tak lepas dari

e-commerce pada umumnya, dan bisnis kuliner online pada khususnya. Aktivitas ekonomi ini tentu saja berdampak pada pertumbuhan ekonomi Kota Semarang.

\section{Rumusan masalah}

Dari latar belakang penelitian di atas maka rumusan masalah untuk penelitiannya adalah bagaimana bisnis kuliner online dapat meningkatkan pertumbuhan ekonomi di kota Semarang. Dari rumusan masalah tersebut maka pertanyaan penelitiannya adalah sebagai berikut:

1. Mengapa pengusaha kuliner tertarik menggunakan media online untuk memasarkan produk makanannya?

2. Bagaimana pengaruh bisnis kuliner online terhadap omset yang diperoleh ?

3. Bagaimana media online dapat membuka kesempatan bagi pengusaha kuliner untuk memperluas pemasarannya?

4. Seberapa besar sumbangan bisnis kuliner terhadap sektor makanan dan minuman secara umum di Kota Semarang?

\section{Tinjauan Pustaka}

\section{Pertumbuhan Ekonomi}

Pertumbuhan ekonomi menurut Kunarjo (2003:88) "adalah situasi yang menggambarkan produk domestik bruto per kapita suatu negara yang mengalami peningkatan". Para ekonom lainnya seperti Nanga (2001:273) mengungkapkan "secara umum, pertumbuhan ekonomi didefinisikan sebagai peningkatan dalam kemampuan dari suatu perekonomian dalam memproduksi barang-barang dan jasa-jasa".

Pertumbuhan ekonomi lebih menunjukkan pada perubahan-perubahan yang bersifat kuantitatif dan biasanya diukur dengan data produk domestik bruto GDP). Produk domestik bruto adalah total nilai pasar dari barang-barang akhir dan jasa-jasa yang dihasilkan di dalam suatu perekonomian selama kurun waktu tertentu (Nanga 2001:274).

Pengertian pertumbuhan ekonomi harus dibedakan dengan pembangunan ekonomi. Pertumbuhan ekonomi hanyalah merupakan salah satu aspek saja dari pembangunan ekonomi yang lebih menekankan pada peningkatan output agregat khususnya output agregat per kapita.

Pertumbuhan ekonomi dapat diartikansebagai proses perubahan kondisi perekonomian suatu negara secara berkesinambungan menuju keadaan yang lebih baik selama periode tertentu. Pertumbuhan ekonomi dapat diartikan juga sebagai proses kenaikan kapasitas produksi suatu perekonomian yang diwujudkan dalam bentuk kenaikan pendapatan nasional.

Perekonomian dikatakan mengalami pertumbuhan apabila jumlah balas jasa riil terhadap penggunaan faktor-faktor produksi pada tahun tertentu lebih besar daripada tahun sebelumnya.Indikator yang digunakan untuk menghitung tingkat Pertumbuhan Ekonomi

- Tingkat Pertumbuhan PDB (Produk Domestik Bruto)

- Tingkat Pertumbuhan PNB (Produk Nasional Bruto)

Dalam praktek angka, PNB kurang lazim dipakai, yang lebih populer dipakai adalah PDB, karena angka PDB hanya melihat batas wilayah,terbatas pada negara yang bersangkutan.

Pertumbuhan ekonomi dihasilkan dari interaksi-interaksi faktor-faktor produksi. Output barang dan jasa yang dihasilkan oleh suatu perekonomian bergantung pada kuantitas input yang tersedia seperti kapital dan tenaga kerja, dan produktifitas dari input tersebut.Sukirno (2005:448) mengemukakan mengenai faktor-faktor yang akan menimbulkan pertumbuhan ekonomi: 
Dinamika Sosial Budaya, Vol 20, No. 2, Desember 2018, pp 120-133

p-ISSN: 1410-9859\& e-ISSN: 2580-8524

http://journals.usm.ac.id/index.php/jdsb

1. Peranan sistem pasar bebas.

Sistem mekanisme pasar akan mewujudkan kegiatan ekonomi yang efesien dan pertumbuhan ekonomi yang teguh. Oleh sebab itu pemerintah tidak perlu melakukan kegiatan ekonomi yang menghasilkan barang dan jasa. Fungsi pemerintah perlulah dibatasi kepada menyedikan fasilitasfasilitas yang menggalakkan perkembangan kegiatan pihak swasta, menyediakan infrastruktur, mengembangkan pendidikan dan menyediakan pemerintah yang efesien adalah beberapa langkah yang akan membantu pihak swasta.

\section{Perluasan Pasar}

Perusahaan-perusahaan melakukan kegiatan produksi dengan tujuan untuk menjualnya kepada masyarakat dan mencari untung. Semakin luas pasaran barang dan jasa, semakin tinggi tingkat produksi dan tingkat kegiatan ekonomi. Pentingnya juga pasaran luar negeri dalam mengembangkan kegiatan di dalam negeri.

\section{Spesialisasi dan kemajuan tekhnologi}

Perluasan pasar, dan perluasan kegiatan ekonomi yang digalakkannya, akan memungkinkan spesialisasi dalam kegiatan ekonomi. Seterusnya spesialisasi dan perluasan kegiatan ekonomi akan menggalakkan perkembangan tekhnologi dan produktivitas meningkat. Kenaikan produktivitas akan menaikkan pendapatan pekerja dan kenaikan ini akan memperluas pasaran. Keadaan ini akan mengembangkan spesialisasi. Siklus ini akan mengakibatkan perekonomian terus berkembang.

\section{Internet}

Internet (Interconnected Network) adalah jaringan-jaringan komputer yang saling terkoneksi satu sama lain. Internet memungkinkan orangorang atau perusahaan-perusahaan di seluruh dunia untuk saling berkomunikasi suatu sama lain secara efektif dan murah. Sesuai dengan kepanjangannya, internet terdiri dari sekumpulan jaringan komputer milik perusahaan, institusi, lembaga pemerintah, ataupun penyedia jasa jaringan (ISP/internet service provider) yang saling terhubung dimana masing masing jaringan komputer yang dikelola secara independen. Pengembangan internet sendiri sebenarnya sudah mulai dirintis sejak tahun 1960an sebagai proyek dari departemen pertahanan amerika serikat. Internet menjadi salah satu media yang dijadikan sumber informasi paling populer antar mahasiswa perguruan tinggi di dunia. Penggunaan internet telah menjadi sebuah gaya hidup (life style) bagi sebagaian besar mahasiswa perguruan tinggi di seluruh dunia. Bagi mereka internet adalah sebuah alat fungsional yang telah mengubah caraseseorang berinteraksi dengan orang lain, maupun dalam menemukan informasi. Banyak diantara mahasiswa yang menggunakan internet untuk menyelesaikan berbagai kepentingan akademis, baik itu dilakukan melalui pertukaran email dengan fakultas, teman sebaya, atapun kepentingan lainnya, termasuk melakukan bisnis online, baik itu sebagai penjual, reseller, maupun pembeli. Dengan kata lain seseorang yang memiliki akses internet dapat berkomunikasi langsung dengan seseorang yang lain, membuat informasi yang bermanfaat bagi orang lain, menemukan informasi-informasi yang disediakan orang lain atau menjual dan membeli produk-produk tertentu dengan biaya yang minimum dengan jaringan yang terhubung secara global. Dalam perkembangannya, internet mempunyai nilaibisnis antara lain;

a. Meningkatkan loyalitas pelanggan saat ini melalui perbaikan dan dukungan.

b. Peningkatan kebutuhan informasi pada masyarakat informasi, khususnya kalangan akademik dan pebisnis dirasakan semakin meningkat akibat adanya saling keterkaitan dan ketergantungan individu terhadap informasi. 
Dinamika Sosial Budaya, Vol 20, No. 2, Desember 2018, pp 120-133

p-ISSN: 1410-9859\& e-ISSN: 2580-8524

http://journals.usm.ac.id/index.php/jdsb

c. Email ; yaitu aktivitas komunikasi dalam bentuk surat-menyurat dalam bentuk surat elektronik.

d. Aktivitas kesenangan (fun activities), yaitu aktivitas yang sifatnya untuk kesenangan atau hiburan seperti : online untuk bersenang-senang, klip video atau audio, pesan singkat, mendengarkan atau mendownload musik, bermain game, chatting;

e. Kepentingan informasi (information utility), yaitu aktivitas internet untuk mencari informasi, seperti : informasi produk, informasi travel, cuaca, informasi tentang film, musik, buku, berita, sekolah, kesehatan, pemerintah,keuangan, pekerjaan, dan informasi tentang politik;

f. Transaksi (transaction), yaitu aktivitas transaksi (jual beli) melalui internet seperti : membeli sesuatu, memesan tiket perjalanan, online banking, dan lain-lain.

Diantara banyak kebutuhan manusia, kebutuhan yang paling mencolok peningkatannya adalah kebutuhan akan informasi. Oleh karena itu pemilihan sumber informasi menentukan seseorang terhadap pemenuhan kebutuhannya. Disamping itu, pemilihan sumber informasi seseorang juga didasarkan pada pola kebiasaan. Meyers, Nathan, dan Saxton menyatakan bahwa pola kebiasaan diartikan bila di masa lalu sebuah sumber informasi dapat memenuhi kebutuhan seseorang maka ia akan cenderung menggunakan sumber informasi tersebut untuk waktu selanjutnya. Leckie menambahkan bahwa pengetahuan seseorang tentang sumber informasi (awareness of information sources) yang akan digunakan, seperti kecepatan akses (accessibility), kualitas (quality), ketepatan waktu (timeliness), kepercayaan (trustworthiness), kebiasaan (familiarty) dan keberhasilan sebelumnya (previous success) akan berdampak langsung pada pelaksanaan pencarian informasi (information is sought). Sehingga hal inilah yang mendorong seseorang untuk memilih media yang tepat sebagai sumber informasi bagi pemenuhan kebutuhannya.

\section{Bisnis Online / E-commerce}

E-commerce adalah kegiatan-kegiatan bisnis yang menyangkut konsumen (consumers), manufaktur (manufactures), service providers dan pedagang perantara (intermediaries), dengan menggunakan jaringan-jaringan komputer (computer networks) yaitu internet. Dengan kata lain e-commerce adalah merupakan suatu transaksi komersial yang dilakukan antara penjual dan pembeli atau dengan pihak lain dalam hubungan perjanjian yang sama untuk mengirimkan sejumlah barang, pelayanan, atau perahlian hak.

Dalam pengertian lain, e-commerce adalah pembelian dan penjualan, pemasaran dan pelayanan serta pengiriman dan pembayaran produk, jasa dan informasi di internet dan jaringan lainya, antara perusahaan berjaringan dan pelanggan, pemasok, dan mitra bisnis lainya. Shim mendefinisikan $e$ commerce (electronic commerce) sebagai konsep baru yang bisa digambarkan sebagai proses jualbeli barang atau jasa pada World Wide Web Internet. Atau menurut Turban e-commerce merupakan jual beli atau pertukaran produk, jasa dan informasi melalui jaringan informasi termasuk internet. Sedangkan menurut Kalakota dan Whinston (1997) mendefinisikan e-commerce dari beberapa perspektif berikut:

a. Perspektif komunikasi: e-commerce merupakan pengiriman informasi, produk/ layanan, atau pembayaran melalui lini telepon, jaringan komputer atau sarana elektronik lainnya.

b. Perspektif proses bisnis: e-commerce merupakan aplikasi teknologi menuju 
Dinamika Sosial Budaya, Vol 20, No. 2, Desember 2018, pp 120-133

p-ISSN: 1410-9859\& e-ISSN: 2580-8524

http://journals.usm.ac.id/index.php/jdsb

otomisasi transaksi dan aliran kerja perusahaan.

c. Perspektif layanan: e-commerce merupakan salah satu alat yang memenuhi keinginan perusahaan, konsumen dan manajemen dalam memangkas service cost ketika meningkatkan mutu barang dan kecepatan pelayanan.

d. Perspektif online: e-commerce berkaitan dengan kapasitas jual beli produk dan informasi di internet dan jasa online lainnya.

Penggunaan e-commerce pada saat ini merupakan syarat bagi sebuah organisasi atau perusahaan, agar perusahaan itu dapat bersaing secara global. Banyak penelitian yang menekankan efisiensi dalam penggunaan $e$-commerce. Selain itu juga peneliti banyak melihat dampak positif yang diberikan oleh e-commerce dibandingkan dampak negatifnya. Sekarang banyak perusahaan, baik perusahaan kecil atau perusahan besar memanfaatkan e-commerce sebagai upaya meningkatkan bisnisnya. Berdasarkan penelitian dan studi kasus di Australia, ada beberapa faktor yang mendorong perusahaan dalam memanfaatkan e-commerce:

a. Penggunaan komputer dam teknologi informasi oleh sebuah perusahaan.

b. Penerapan e-commerce saat ini, dan rencana dimasa yang akan datang.

c. Kendala dalam penggunaan $e$-commerce.

d. Keahlian dari staff teknologi informasi pada sebuah perusahaan.

\section{Telaah penelitian sebelumnya}

Penelitian yang berjudul "Pengaruh $E$ Commerce terhadap Pertumbuhan Ekonomi Indonesia” oleh Rr. Getha Fety Dianari (2017). Hasil estimasi menunjukkan perkembangan $E$ commerce yang direpresentasikan melalui perkembangan nilai transaksi E-commerce, perkembangan jumlah situs bisnis dan pengguna jumlah internet terbukti berpengaruh positif terhadap pertumbuhan ekonomi Indonesia. Hasil ini membenarkan hipotesis bahwa perkembangan nilai transaksi E-commerce yang dibentuk atas interaksi situs bisnis sebagai indikator penawaran dan pengguna internet sebagai indikator permintaan, berkontribusi pada peningkatan intensitas kegiatan ekonomi makro.

Penelitian yang berjudul "Pengaruh $E$ commerce terhadap peningkatan pendapatan sentra industri kripik pisang Bandar lampung ditinjau dari etika bisnis Islam" oleh Walia (2017). Hasil penelitian menunjukkan variabel E-commerce berpengaruh terhadap peningkatan pendapatan. Penggunaan E-commerce pada sentra industri bahwa manusia harus berusaha merubah keadaannya agar lebih baik seperti halnya penggunaan E-commerce memberikan dampak perubahan terhadap usaha.

Penelitian yang berjudul "Anlisis Perkembangan e-commerce dalam mendorong Pertumbuhan Ekonomi Wilayah Indonesia. Hasil penelitian menunjukkan bahwa dengan adanya perluasan pasar akan berdampak pada kenaikan pertumbuhan ekonomi suatu wilayah.

Penelitian yang dilakukan oleh Tita Yulia Iriani, "Analisis Dampak layanan Go Food Terhadap Omset Penjualan Rumah Makan di Kota Bandung”, Universitas Pasundan, 2017 menunjukkan jumlah pelanggan, omset penjualan, dan biaya operasional rumah makan mereka meningkat jadi lebih anyak setelah bergabung dengan Layanan Go-Food dibandingkan dengan sebelum bergabung dengan Layanan Go-Food, hal ini dikarenakan bahwa salah satu estimasi Go-Food adalah mempromosikan makanan hasil karya industri UKM 
Dinamika Sosial Budaya, Vol 20, No. 2, Desember 2018, pp 120-133

p-ISSN: 1410-9859\& e-ISSN: 2580-8524

http://journals.usm.ac.id/index.php/jdsb

\section{TUJUAN DAN MANFAAT PENELITIAN}

\section{Tujuan penelitian}

Tujuan penelitian ini adalah menjelaskan dan menggambarkan bagaimana bisnis kuliner online melalui go food dapat meningkatkan pertumbuhan ekonomi di kota Semarang (descriptive explanatory research).

\section{Manfaat Penelitian}

Manfaat penelitian ini adalah sebagai berikut:

a) Hasil penelitian ini dapat dijadikan sebagai masukan bagi para pengusaha kecil yang bergerak di bidang kuliner yang belum menggunakan media online untuk memasarkan produk kulinernya melalui media online

b) Diharapkan penelitian ini dapat memberikan kontribusi literatur dan sebagai bukti empiris untuk melengkapi penelitian terdahulu yang erat kaitannya dengan bisnis kuliner online.

c) Hasil penelitian ini dapat meningkatkan jumlah publikasi artikel ilmiah.

\section{METODE PENELITIAN}

\section{Metode Penelitian dan pemilihan informan}

Penelitian ini menggunakan metode kualitatif (qualitativemethod) yaitu sebuah metode yang menurut Creswell (2012) sebagai usaha untuk membangun makna suatu fenomena berdasarkan pandangan-pandangan dari partisipan. Lebh lanjut lagi Strauss dan Corbin (2007) menyatakan bahwa penelitian kualitatif sebagai jenis penelitian yang temuan-temuannya tidak diperoleh dari prosedur statistik atau bentuk hitungan lainnya. Dengan kata lain, peneliti akan bekerja dengan data yang berupa deskripsi. Contohnya dapat berupa penelitian tentang kehidupan, riwayat, perilaku seseorang, disamping juga tentang peranan organisasi, pergerakan sosial atau hubungan timbal balik. Sedangkan pendekatan yang digunakan adalah dengan metode naratif. Metode kualitatif dipilih karena sesuai dengan tujuan penelitian ini, peneliti bermaksud menggambarkan dan menjelaskan bukan mencari hubungan antarvariabel. Dengan demikian, tidak seperti pada penelitian kuantitatif, keterwakilan (representativeness) bukanlah keharusan karena penelitian ini tidak dimaksudkan untuk membuat generalisasi. Hal yang harus diperhatikan dalam penelitian kualitatif adalah konsistensi dan validitas data atau informasi. Oleh karena itu, peneliti harus menggunakan strategi yang dikenal sebagai triangulasi.

Informan adalah orang yang ada dalam setting penelitian yang dapat membantu peneliti dalam pengumpulan data kualitatif. Informan yang dipilih adalah orang-orang yang memiliki kriteria sebagai berikut: pengusaha kuliner yang memasarkan produknya lewat media online lebih dari satu tahun di kota Semarang. Badan Pusat Statistik Kota Semarang atau instansi yang terkait.

\section{Pengumpulan, Pengolahan dan Sintesa Data}

Pada dasarnya data atau informasi akan dikumpulkan melalui pengamatan (observasi) dan interview mendalam (in depth interview) dengan strategi triangulasi guna menjaga konsistensi dan validitas informasi yang diberikan informan atau partisipan. Sebagai bagian dari strategi triangulasi di atas, peneliti selama melakukan wawancara dan pengamatan akan membuat catatan-catatan lapangan (field notes).

Langkah berikutnya adalah analisis dan pengelolaan data. Jane Sutton dan Zubin Austin (2015) mengemukakan, dalam tahap ini peneliti harus melakukan (i) transkrip wawancara dan pengecekan, (ii) coding atau melakukan pengkodean, dan (iii) menentukan tema-tema yang akan diceritakan (theming).

Langkah terakhir dari penelitian kualitatif adalah sintesa data. Langkah ini merupakan "cerita" peneliti mengenai temuan-temuan yang 
Dinamika Sosial Budaya, Vol 20, No. 2, Desember 2018, pp 120-133

p-ISSN: 1410-9859\& e-ISSN: 2580-8524

http://journals.usm.ac.id/index.php/jdsb

dihasilkan selama penelitian supaya bisa dibaca oleh khalayak.

\section{HASIL DAN LUARAN YANG DICAPAI}

\section{Hasil Penelitian}

\section{Gambaran umum obyek penelitian}

Kota Semarang terletak di Provinsi Jawa Tengah merupakan salah satu kota terbesar ke lima di Indonesia. secara Geografis Kota Semarang terletak di bagian Utara Jawa Tengah. Kota Semarang yang memiliki luas wilayah $373,7 \mathrm{~km} 2$ atau seluas $37.369,568 \mathrm{H}$ ini, secara geografis di sebelah barat berbatasan dengan Kabupaten Kendal, di sebelah timur berbatasan dengan Kabupaten Demak, di selatan dengan Kabupaten Semarang, dan di utara dengan Laut Jawa.

Jika dibandingkan dengan

Kabupaten/Kota di Provinsi Jawa Tengah, Kota Semarang dikenal sebagai tempat wisata kuliner karena hampir di setiap sudut kota dipenuhi dengan berbagai macam kuliner, Sub-sektor perdagangan dan jasa seperti hotel, rumah makan, restoran, dan kuliner merupakan dengan demikian merupakan usaha-usaha yang harus dianalisis lebih lanjut sehingga akar usahanya dapat menyentuh perkembangan ekonomi lokal.

Objek penelitian merupakan permasalahan yang diteliti. Objek dari penelitian ini adalah dampak bisnis kuliner melalui Go Food terhadap pertumbuhan ekonomi di kota Semarang. Penelitian ini dilaksanakan didasarkan pada banyaknya bisnis kuliner yang menggunakan media online untuk memasarkan produk makanannya sehingga mempengaruhi omset yang diterimanya dan kaitannya dengan pertumbuhan ekonomi kota Semarang

\section{Profil Informan}

Fokus yang akan diteliti oleh peneliti adalah para pengusaha kuliner yang pengguna jasa
Go Food di wilayah kota Semarang. Dasar peneliti melakukan penelitian karena sekarang sedang maraknya bisnis-bisnis online, termasuk bisnis kuliner online. Perusahaan yang bergerak di bidang kuliner secara online yang sudah beroperasi di kota Semarang adalah perusahaan GOJEK. GOJEK menawarkan jasa kuliner online yaitu berupa go food.

Dengan semakin mudahnya masyarakat mendapatkan kuliner melalui go food, maka akan semakin ketat persaingan antar pengusaha kuliner, e commerce mempunyai dampak yang sangat banyak bagi pebisnis, konsumen maupun masyarakat. Dampak tersebut tentu saja akan mendorong pertumbuhan ekonomi wilayah lebih cepat daripada perdagangan konvensional yang mengharuskan adanya tatap muka antara penjual dan pembeli (suyanto:2003)

Hasil wawancara yang dilakukan peneliti terhadap beberapa informan yang dalam hal ini adalah pengusaha kuliner, diperoleh beberapa informasi berkaitan dengan profesi mereka. Wawancara dilakukan terhadap empat pengusaha kuliner. Berikut adalah profil dari para informan:

1. Ayu berusia 43 tahun, menekuni profesi sebagai pengusaha kuliner sejak tahun 2008. Ayu mempunyai suami dan 2 anak, dipilihnya ayu nara sumber karena usaha kuliner ini merupakan sumber penghasilan utama untuk menafkahi keluarganya. Dia mulai membuka kedai soto nya sejak pukul 06.30 WIB sampai pukul 20.00 WIB. Sebelum menjadi pengusaha kuliner ayu pernah gagal dalam menjalankan bisnisnya antara lain sebagai pengusaha garment, pengusaha isi ulang air, pengusaha sablon Ayu dijadikan oleh peneliti sebagai informan dengan alasan bahwa dia sudah menekuni bisnis kuliner cukup lama yaitu selama 3 tahun dan menggunakan aplikasi gofood selama 2 tahun. 
Dinamika Sosial Budaya, Vol 20, No. 2, Desember 2018, pp 120-133

p-ISSN: 1410-9859\& e-ISSN: 2580-8524

http://journals.usm.ac.id/index.php/jdsb

2. Mega Kurnia Dewi berusia 42 tahun, mempunyai 4 orang anak. Sebelum menekuni bisnis kuliner Mega adalah seorang karyawati Di PT Telkom Semarang. Mega menekuni bisnis kuiner sejak tahun 2012. Dia menekuini bisnis kuliner ini sebagai penghasilan utama untuk menafkahi keluarganya Alasan mengapa peneliti memilih Mega sebagi informan dikarenakan mega menggunakan aplikasi go food sejak pertama kali aplikasi go food dibuka di semarang.

3. Dwi Supriyati 59 tahun, menekuni bisnis kuliner sejak tahun 2003. Supriyati sebagai tulang punggung keluarga mempunyai 10 anak. Bisnis sampingan yang dilakukan oleh supriyati adalah berdagang berbagai macam barang . Alasan mengapa peneliti memilih Supriyati sebagai informan karena dia sudah lama menekuni bisnis kuliner sebagai penghasilan utama dan menggunakan aplikasi gofood.

4. Sartono berusia 33 tahun, memulai usaha kuliner sejak tahun 1995. Sartono memiliki istri and 2 orang anak. Istri Sartono mempunyai usaha ayam penyet pada tahun 2000 tetapi karena tidak dapat bertahan dalam persaingan dan mengalami kerugian yang terus menerus maka usaha tersebut sudah ditutup dan membuka usaha baru yaitu Mie Jowo. Sartono menjadikan usaha kuliner ini sebagai sumber penghasilan utama untuk menafkahi keluarganya. Alasan mengapa peneliti memilih Sartono menjadi salah satu informan adalah karena dia berprofesi sebagai pengusaha kuliner cukup lama dan masih tetap ingin mempertahankan profesi ini sebagai sumber penghasilan utama.

\section{Gambaran Penelitian}

Informan I
Berdasarkan hasil wawancara peneliti terhadap para informan, diantaranya adalah informan I bernama Ayu (43 tahun) mengatakan bahwa yang membuat Ayu membuka bisnis kuliner dikarenakan subah beberapa kali mengalami kegagalan bisnis. Bisnis kuliner tersebut dimulai sejak tahun 2014 atau sekitar 4 tahun yang lalu. Pada awal mengelola bisnis kuliner Ayu mengalami masa masa sulit di dalam mengenalkan produknya pada masyarakat. Hal tersebut dapat dilihat dari sedikitnya konsumen yang berkunjung pada kedai yang dimilikinya. Jumlah konsumen konsumen yang sedikit tersebut mempengaruhi jumlah omzet yang diterimnanya yaitu sebesar kurang lebih Rp.50.000 sampai dengan Rp.70.000 per hari. Untuk bisa tetap beroperasi di tengah persaingan bisnis kulinernya ayu meningkatkan layanan bagi para konsumen dengan cara berkomunikasi untuk mendapatkan berbagai masukan mengenai produknya, meningkatkan kualitas dan kuantitas produk yaitu dengan cara merubah komposisi dari bumbu yang sudah ada dan menambah jenis masakan yang dijualnya selain itu juga menambah jumlah kedai dengan membuka cabang baik di semarang maupun dluar kota semarang.

Ayu mulai menggunakan strategi online semenjak akhir 2016 di bulan November dengan tujuan untuk memasarkan produknya agar dapat menjaring konsumen diberbagai kalangan sehingga omset akan meningkat. Keuntungan yang diperoleh setelah mendaftar pada aplikasi gojek mkelalui gofood adalah adanya peningkatan omset perbulan yaitu kurang lebih sebesar $30 \%$.

Informan II

Informan kedua dalam penelitian ini adalah Mega (42 tahun) Mega meninggalkan pekerjaanya sebagai karyawati di PT Telkom dikarenakan kondisi keluarga yang tidak terurus. Mega menekuni bisnis kulinernya karena 
Dinamika Sosial Budaya, Vol 20, No. 2, Desember 2018, pp 120-133

p-ISSN: 1410-9859\& e-ISSN: 2580-8524

http://journals.usm.ac.id/index.php/jdsb

merupakan sumber penghasilan utama untuk memenuhi kebutuhan hidup keluarganya. Pada tahun 2012 Mega mulai menekuni bisnis kuinernya. Mega memperoleh omset rata-rata sebesar Rp. 250.000 per hari, hal itu berlangsung kurang lebih selama 2 tahun. Tahun 2015 aplikasi gojek mulai hadir di kota Semarang, pada saat itulah Mega mendaftarkan produknya pada aplikasi gojek melalui go food. Ketertarikan menggunakan teknologi baru ini berdasarkan pada keinginan bisa bertahan ditengah persaingan dan untuk memperluas pemasarannya dengan harapan omset bisa meningkat. Omzet meningkat secara signifikan dengan rata rata sebesar Rp.450,000 pada tahun petama. Saat ini Mega mengembangkan produknya dengan menambah pilihan kuliner lain seperti salad buah mayonais, salad buah yakult, rujak sambal kacang dan mede, asinan sayur. Di tahun 2018 rata-rata omzet yang diterima Mega sebesar Rp.1400.000 perhari.

Informan III

Informan ketiga dalam penelitian ini adalah Dwi Supriyati (59 tahun). Dwi Supriyati mengungkapkan bahwa dia tetap ingin mempertahankan profesinya sebagai pengusaha kuliner upaya mendapatkan penghasilan utama. Dwi supriyati merasakan bisnis kuliner ini dapat menjamin hidupnya. Dwi Supriyati mengalami masa masa paling sulit pada tahun 2004 yang diakibatkan adanya persaingan bisnis. Didalam pengembangan bisnis kuliner terjadi npada tahun 2003 dengan omset Rp.400.000 kemudian meningkat pada tahun 2006 menjadi Rp.800.000 perhari dan pada tahun 2012 menjadi Rp.1500.000 perhari. Di awal tahun 2017 omset naik kembali menjadi Rp.2000.000/ hari. Seiring dengan perkembangan teknologi pada pertengan tahun 2017 supriyati mulai memperluas pemasaran bisnis kulinernya dengan menggunakan aplikasi gofood dengan harapan bisa lebih mengenalkan bisnisnya pada berbagai kalangan masyrakat. Setelah menggunakan go food omset yang diperoleh supriyati mengalami kenaikan rata-rata Rp.6000.000 per hari.

Informan IV

Informan yang keempat dalam penelitian ini adalah Sartono (33 tahun). Faktor yang menyebabkan Sartono tetap ingin mempertahankan bisnis kulinernya adalah karena profesi ini sebagai sumber penghasilan utamanya untuk menghidupi keluarganya. Pasang surut dari usaha kuliner tentu saja dirasakan oleh Sartono terutama pada saat krisis moneter tahun 1998. Setelah melewati masa tersebut Omset yang diperoleh Sartono dari tahun ke tahun mengalami peningkatan . Pada tahun 1995 omset rata-rata yang diperolehnya yaitu sekitar Rp.15.000 perhari. Pada tahun 2016 rata rata omset yang diperolehnya meningkat sebesar Rp. 70.000. Untuk mengembangkan pemasarannya dan bertahan ditengah persaingan maka pada tahun 2017 Sartono memulai menggunakan aplikasi gojek melalui go food. Setelah menggunakan aplikasi tersebut omset Sartono mengalami peningkata secara signifikan sebanyak $100 \%$ yaitu pada tahun 2017 sebelum menggunakan aplikasi gofood 70.0000 dan satu tahun kemudian setelah memakai aplikasi gofood omzet menjadi 1.500.000 per hari. Untuk memenuhi permintaan konsumen ,Sartono yang sebelumnya yaitu pada akhir tahun 2017 hanya mempekerjakan 3 orang karyawan sekarang sudah menjadi 6 orang karyawan. Dari keterangan tersebut membuktikan bahwa bisnis kuliner bakmi jowo Sartono menjadi penghasilan utama keluarga.

Untuk bisa tetap bisa bersaing dengan bisnis kuliner yang menjamur di kota Semarang Sartono mengungkapkan hal yang sama dengan informan lain yaitu perlu adanya promosi secara online melalui gofood.

\section{Pembahasan}


Dinamika Sosial Budaya, Vol 20, No. 2, Desember 2018, pp 120-133

p-ISSN: 1410-9859\& e-ISSN: 2580-8524

http://journals.usm.ac.id/index.php/jdsb

Observasi dalam penelitian ini dilakukan selama 2 minggu. Wawancara dilakukan pada para pemilik bisnis kuliner yang menggunaka aplikasi gojek melalui go food, di Semarang dan data yang berasal dari BPS kota Semarang.

Berikut ini adalah data informan yang berpengaruh terhadap tingkat pertumbuhan ekonomi yaitu Ayu (43 tahun) pemilik kedai Soto Seger Kartosuro, Mega Kurnia Dewi (42 tahun) pemilik Asinan Mega, Sartono (43 tahun) pemilik Mie Jowo mas NO, Dwi supriyati (59 tahun) pemilik Sop Kaki Kambing Bang Jaya, pegawai gojek semarang, Dari latar belakang yang berbeda beda dari berbagai informan, mereka memberikan jawaban untuk rumusan masalah yang pertama yaitu tentang Ketertarikan menggunakan media online.

Berikut uraian informan:

- Ketertarikan menggunakan media online disebabkan karena adanya kemudahan dalam delivery order yaitu dengan membuka fitur aplikasi go food dalam aplikasi gojek. Pelayanan delivery order dapat dilakukan tanpa harus menyediakan armada (Ayu)

- Ketertarikan menggunakan media online agar dapat bertahan ditengah persaingan, kemudahan di dalam pengiriman barang yang tadinya dikirim sendiri saat ini hanya menyiapkan saja tanpa harus kehilangan banyak waktu, tidak harus menyediakan tempat untuk produknya (Mega)

- Ketertarikan menggunakan go food dikarenakan mencoba memanfaatkan teknologi baru, mempermudah pengiriman, cepat dikenal orang, mengoptimalkan peluang bisnis (Dwi Supriyati)

- Ketertarikan penggunakan media online, mempermudah pengiriman, mempercepat pelayanan
Dari penjelasan para informan tentang ketertarikan menggunakan go food mayoritas menyatakan adanya kemudahan didalam pengiriman, mempercepat pelayanan, menghemat waktu dan menghemat biaya dibandingkan sebelum menggunakan aplikasi go food

Jawaban informan mengenai Pengaruh bisnis kuliner terhadap omset

- Meskipun sudah beberapa lama menggeluti bisnis kuliner, ayu baru satu tahun 2 bulan menggunakan aplikasi go food, semenjak menggunakan aplikasi gofood Soto Seger Kartosuro mempunyai omset yang meningkat, dari Rp.2000.000/hari menjadi Rp.2500.000/ hari bahkan pada saat hari sabtuminggu atau pada hari libur bisa mencapai kurang lebih Rp. 6000.000 (Ayu)

- Omset yang diterima asinan Mega selama menggunakan aplikasi gofood mengalami fluktuasi meskipun selalu mengalami kenaikan dibandingan saat sebelum menggunakan go food. Omzet yang diterima saat ini mencapai 450.000 per hari dibandingkan sebelum menggunakan go food sebesar Rp.70,000 perhari.

- Omset yang diterima bakmi Jowo mas No meningkat secara signifikan yaitu meningkat lebih dari $100 \%$ bila dibandingkan saat sebelum menggunakan gofood. Omset yang diperoleh yaitu sebesar Rp.1.500.000/hari Dimana sebelumnya hanya Rp.700.000/hari (Sartono)

- Kenaikan Omset Sop kaki kambing Bang Jaya tidak begitu banyak pada saat menggunakan go food. Kenaikan omset per hari rata-rata sebesar Rp.1000.000 yang semula Rp.6000.000 per hari menjadi Rp.7000.000.

Dari penjelasan para informan berkaitan dengan omset yang diperolehnya mayoritas mayoritas menyatakan adanya kenaikan omset setelah 
Dinamika Sosial Budaya, Vol 20, No. 2, Desember 2018, pp 120-133

p-ISSN: 1410-9859\& e-ISSN: 2580-8524

http://journals.usm.ac.id/index.php/jdsb

menggunakan aplikasi go food meskipun ada pula yang menyatakan kenaikannya hanya sedikit saja.

Jawaban informan mengenai perluasan pemasarannya setelah menggunakan go food

- Media online dalam hal ini adalah go food. Penggunaan media online merupakan suatu teknologi yang baru untuk memperluas jaringan pemasaran, sebelum menggunakan media online pemasaran Soto Seger Kartosuro hanya terbatas sekitar Banyumanik saja. Perluasan pemasaran setelah menggunakan media online meliputi berbagai daerah di kota Semarang seperti Pandanaran, Perumahan Elang, Tanah Mas, Manyaran, Perumahan Tlogosari, Mijen (Ayu)

- Penggunaan go food memberikan jaringan pemasaran yang lebih luas dibandingan pemasaran secara konvensional, yaitu dengan cara menitipkan pada teman-temannya, pada toko atau supermarket yang ada seperti Gelael, dan beberapa toko buah di Semarang. Setelah menggunakan go food jangkauan pemasaran Asinan Buah Mega menjadi lebih luas sampai ke luar kota seperti Jepara, Kendal, Ungaran, Bawen, Salatiga. (Mega)

- Ketertarikan menggunakan media online dikarenakan kemudahan untuk memasarkan bisnis kulinernya, meskipun dalam kondisi sehari-hari sudah mempunyai pelanggan tetap mulai dari kalangan pejabat seperti Walikota, Kapolres. Dengan menggunakan media online produknya akan semakin dikenal masyarakat (Dwi Supriyati)

- Go food sangat membantu dalam pemasaran Bakmi Jowo mas No, sebelum manggunakan media tersebut Sartono hanya menjual bakminya untuk konsumen yang berada di sekitar Simpang Lima. Setelah menggunakan go food, bakmi jowo mas No mempunyai konsumen dari berbagai kalangan, Perluasan pemasaran yang dilakukan mas No dengan menggunakan aplikasi go food berdampak pada pesanan yang semakin meningkat. Bakmi joowo mas No banyak mendapatkan pesanan dari berbagai perusahaan/kantor, tamu-tamu yang menginap di hotel, Rumah Sakit Roemani, Rumah Sakit Kariadi, Rumah Sakit Hermina, Rumah Sakit Telogorejo. Selain Bakmi Jowo Mas No juga semakin dikenal oleh masyarakat luas seperti daerah Pedurungan dan Ngaliyan. (Sartono)

- Dari penjelasan para informan tentang perluasan pemasaran menggunakan go food mayoritas menyatakan semakin banyak konsumen yang datang untuk membeli produknya.

- Masyarakat tertarik menggunakan media online dalam hal ini adalah go food dikarekan adanya kemudahan bagi pengguna dalam memperoleh kuliner tanpa perlu menyediakan waktu mendatangi penjual. Dari segi pebisnis kuliner akan memberikan kesempatan dapat mengoptimalkan peluang bisnis yang ada, salah satunya adalah mempromosikan hasil kreasi usahanya yaitu makanan yang enak dengan kualitas yang bagus dapat dipromosikan melalui gofood (astuti)

Jawaban mengenai sumbangan bisnis kuliner terhadap sektor makanan dan minuman secara umum di Kota Semarang

- Sumbangan bisnis kuliner kota semarang mengalami peningkatan dari tahun ke tahun dalam juta yaitu 18.953.603,09 (2015) menjadi 20.503.864,20 (2016) atas dasar harga berlaku, sedangkan menurut harga konstan 16.370.940,88 menjadi 17.264.313,85 (BPS)

\section{Proposisi}


Dinamika Sosial Budaya, Vol 20, No. 2, Desember 2018, pp 120-133

p-ISSN: 1410-9859\& e-ISSN: 2580-8524

http://journals.usm.ac.id/index.php/jdsb

1. Semakin banyak pengguna ecommers maka semakin meningkatkan transaksi kuliner

2. Semakin tinggi nilai transaksi maka akan semakin meningkatkan omset penjualan

3. Semakin tinggi PDRB maka akanmeningkatkan pertumbuhan ekonomi meningkatkan kegiatan ekonomi

\section{Teori Mini}

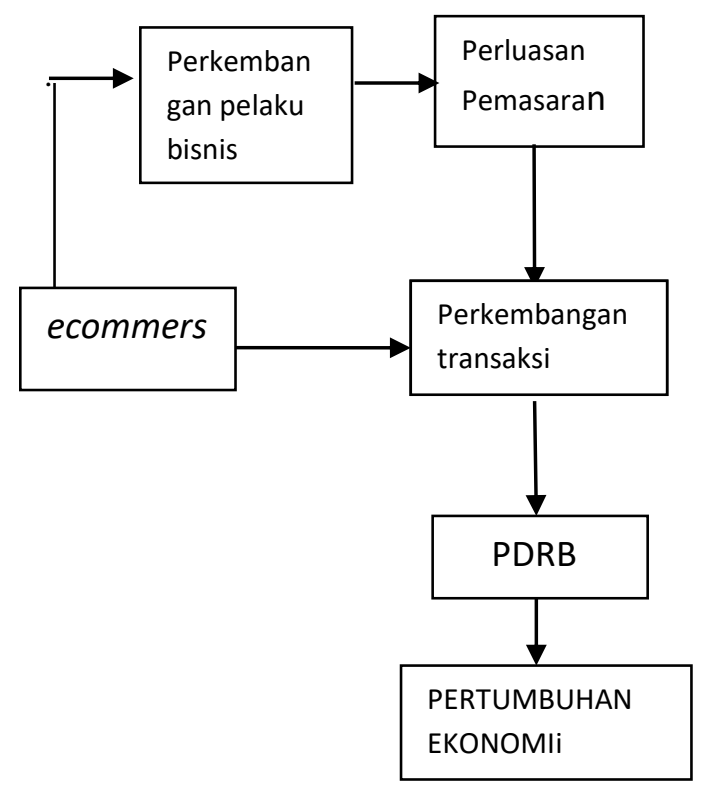

\section{Luaran yang dicapai}

Luaran yang dicapai pada penelitian ini adalah publikasi ilmiah pada Jurnal Solusi yang akan diterbitkan pada bulan Juli 2018

\section{PENUTUP}

\section{Simpulan}

Berdasarkan hasil penelitian dan pembahasan sebelumnya, maka dapat ditarik kesimpulan sebagai berikut: faktor yang menyebabkan kenaikan pertumbuhan ekonomi salah satunya disebabkan oleh sumbangan PDRB pada sector perdagangan dalam hal ini adalah semakin banyaknya pengusaha kuliner khususnya yang menggunakan ecommers .semakin banyaknya transaksi maka akan meningkatkan PDRB yang akhirnya meningkatkan pertumbuhan ekonomi Saran

Berdasarkan hasil dan pembahasan penelitian, maka saran yang bisa diberikan untuk pengusaha kuliner yang sudah mempergunakan go food tetapi belum terjadi peningkatan omset yang signifikan adalah meningkatkan kualitas pelayanannya agar bisa menarik konsumen lebih banyak sehingga nilai transaksi meningkat.

\section{Keterbatasan penelitian}

Keterbatasan dalam penelitian ini adalah bahwa penelitian ini hanya menggunakan lima informan saja sebagai narasumber dan wilayahnya terbatas pada kota Semrang saja.

\section{Penelitian yang akan datang}

Untuk penelitian selanjutnya bisa ditambah informannya supaya mendapatkan lebih banyak informasi dan wilayahnya diperluas menjadi wilayah Jawa Tengah.

\section{Daftar Pustaka}

Budi Widagdo, Prasetyo, “Analisis Perkembangan E-Commerce dalam mendorong Pertumbuhan Ekonomi Wilayah Indonesia", UGM,2016

Dainari, Getha Fety Rr, "Pengaruh

E- Commerce terhadap Pertumbuhan

Ekonomi Indonesia, (2017)

Gunawan, Imam, Metode Penelitian Kualitatif Teori dan Praktek, Bumi Aksara, Jakarta, 2014

Internet:

https://finance.detik.com/berita-ekonomi-bisnis/d3530708/semarang-penyangga-utamapertumbuhan-ekonomi-jateng

https://semarangkota.bps.go.id/

https://ekbis.sindonews.com/read/1177467/33/pertu mbuhan-ekonomi-jawa-tengah-2016melambat-1486378908

Quick, J. dan S Hall. 2015. Qualitative Research. United Kingdom: The Association for Perioperative Practice.

Sutton, Jane dan Zubin Austin. 2015. Qualitative Research: Data Collection, Analysis, and Management. United Kingdom: CJHP. 
Dinamika Sosial Budaya, Vol 20, No. 2, Desember 2018, pp 120-133

p-ISSN: 1410-9859\& e-ISSN: 2580-8524

http://journals.usm.ac.id/index.php/jdsb

Tita Yulia Iriani, “Analisis Dampak

layanan G Food Terhadap Omzet Penjualan

Rumah Makan di Kota Bandung”,

Universitas Pasundan, 2017

Walia, "Pengaruh E-commerce terhadap

peningkatan pendapatan sentra industri kripik pisang Bandar lampung ditinjau dari etika bisnis Islam”, 2017

Nurgiyantoro, Singgih. 2014. "Pengaruh

Strategi Promosi Melalui Social Media

Terhadap Keputusan Pembelian Garskin

Yang Dimediasi Word Of Mouth

Marketing (Studi Pada Konsumen Produk

Garskin Merek Sayhello Di Kota

Yogyakarta)." Yogyakarta. Universitas

Negeri Yogyakarta 